\title{
The Influence of Information Communication Technology (ICT) Integration on Teaching and Learning in South African Schools
}

\author{
Meladi, O. Makgati ${ }^{1}$, Olawumi D. Awolusi² \\ ${ }_{1}^{1}$ University of Roehampton, London, UK \\ ${ }^{2}$ Kampala International University, Kampala, Uganda \\ meladi.makgati@roehampton-online.ac.uk, awolusi.olawumi@kiu.ac.ug
}

\begin{abstract}
Despite the recent emphasis on the quality of education for all in South Africa, the department of education still faces major challenges that hinder the progress of implementing quality education, especially in rural areas. Consequently, this study followed an action qualitative method. The overall purpose of the study was to determine the influence of ICT integration in on the quality of teaching and learning in the classroom and to further examine the benefits of using ICT to enhance personal growth, individual performance, critical thinking skills reading and writing skills. The research questions were semi-structured and open-ended. The researcher interviewed nine (9) learners and seven (7) teachers in a two-session focus group, the first session involved only teachers and the last session had only grade, 12 learners. The themes of the sessions were documented separately; however, the relationship between the themes was identified. The study also performed an observation in the classroom to access situations that would have been almost impossible to identify in an interview or a questionnaire. Results showed that a lot still needs to be done by the government to initiate the process of integrating ICT in education or empower teachers with ICT skill and to do away with the traditional teaching method. The study, however, concluded on the positive influence of ICT integration on teaching and learning practices in the classroom for both teachers and learners. Consequently, the study recommends the following: government must provide training and incentives to encourage personal development in teachers and for young graduates to value teaching; policies about lost equipment must be drafted and understood by all parties; deployments of technology innovation, as well, as the imperatives of following the recommendation of UNESCO's four stages of ICT integration.
\end{abstract}

Keywords: Information Communication Technology (ICT); ICT integration; action qualitative method; educational intervention; South Africa.

\section{Introduction}

The challenges of education in South Africa are not new, there were always visible from Bantu education, to 1994 when South African was promised the quality of education in a new democratic country and up to now the department of basic education is still addressing the challenges of quality education. Although there is visible progress, there are also new emerging challenges and the dimension of the causes. Over the past four years, the Department of Basic Education has experienced a steady decline in South Africa's matric pass rate from $78.9 \%$ in 2013 to $70.2 \%$ in 2015 (Pitan \& Muller, 2019a; DBE, 2017). There is a multitude of published challenges that causes the downward trend of matric performance such as under-qualified teachers, lack of school libraries, not enough textbooks for the learner, lack of motivation to push to learn from their communities and societies, and no culture of reading (Meenakshi, 2013; Faggella-Luby \& Deshler, 2008). This shortcoming of school education poses a tremendous challenge in higher education because student enters into the higher education institutions academically unprepared. The research done by the Council of Higher Education (CHE) in 2015 stated that more than half of the student.

Dropout during their first year (Meenakshi, 2013) this results from the student who enters into higher learning without being academically ready for the transition and other life issues such as finances. The poor performance of high school learners does not only affect the success rate of higher education but the national development as a whole (Awolusi \& Atiku, 2019; Oladejo \& Awolusi, 2018). Since the post-apartheid in 1994, the South African government has been trying to address the challenges of providing quality education, however, more than 20 years later, despite the progressive policy markers the performance and quality of education in schools remains sub-standard (Meenakshi, 2013). The matter is urgent because of South African pupils "persistently low performance in academic achievement" (DBE, 2016). Information and Communication Technology has a great impact in people's lives it has changed almost everything about how 
we do things in a daily basis from the online shopping, card payments, social media, information sources (search engines) (Asika \& Awolusi, 2013; 2015).

It is no doubt that the future of ICT is infinity. Integrating Information and Communication Technology. Into education can improve the quality of education and performance (Asrar-ul-Haq \& Kuchinke, 2016; Awolusi, 2013a; Awolusi, 2013b). The qualitative study, therefore, explored the importance of Information Communication Technology in schools. The study explored the benefits and the influential factor of integrating ICT into schools. The study also provided a brief comparison of how ICT in school is implemented in other countries and their achievements in this regard. The research of information communication technology in schools is becoming more necessary because ICT is constantly changing the way we do things and the current research yields few conclusive statements, most focusing on the advantage and disadvantages of the impact of ICT in schools. South Africa has a significant history of education which cannot be ignored when we discuss the future and the transformation in education. In 1994 South Africa took a transition politically, eliminating Bantu education act for better quality education for all. Bantu education act was introduced in 1953 during the apartheid era, establishing a new black education department within the department of native affairs (Hartshorne, 1992). The role of the department was to create a curriculum that discriminated black pupils from receiving equal education experience as to white pupils (Kallaway, 1984).

The black education curriculum was designed to ensure that black pupils receive a limited education that will make them work manual labouring jobs under whites (Faggella-Luby \& Deshler, 2008). Although Bantu education allowed black children to attend school, however, with severe lack of learning, material and limitation (Meenakshi, 2013; Faggella-Luby \& Deshler, 2008). Since 1994 South African education has undergone major transformation establishing a new department called Department of Education and currently separated into two departments namely, the Department of Basic Education comprised of public, private schools, early childhood development and special needs schools, and has over 12 million learners across the country (DOE, 2015) and the second department is the department of higher education and training. The mandate of the Department of Basic Education is to improve the quality of teaching and learning, this includes improving teacher's capacity and practice, as well as, increasing access of high-quality materials (DBE, 2017). The mandate was part of the documented strategy in 1996 to redress the inequality of apartheid education. Even though there has been a progressive policy and legislation amendments providing quality education is still a major challenge for the department (Meenakshi, 2013).

That notwithstanding, the department of education still strive to provide quality education for all as a result of the following strategic reasons:

- To reduce poverty and contributes to the national development of the country.

- It seems to be the only way a black child can regain the pride that was diminished during apartheid.

- To reduce crime and corruption rate.

- Education amongst women can decrease the maternal mortality rate.

The department introduced several curriculum changes to improve the quality of education in South Africa, the first curriculum was launched in 1997 March called curriculum 2005, which was part of Outcome-Based Education (Jansen, 1998). The concept of OBE has been defined differently by different people in theory or practice. Archer (2014) explains OBE as 'a learner-centred approach to education that focuses on what a student should be able to do in the real world upon completion of their course or program'. The curriculum was seen at the first curriculum reform that will break the inequality of education, improve learner's performance and prepare them for future prosperity (Jansen, 1998), the OBE curriculum had a broad framework that allows teachers to create their learning programmes and teaching materials (Chisholm, 2003).

The initiatives of OBE and curriculum 2005 bought benefits such as (1). It provided guidelines for improving the quality of teaching and learning (2). It provided a study context that learners will need to apply in a reallife situation (3). Promote self-directed and independent learning approach; this is just a few of the benefits. However, the department of basic education experience lots of challenges during the implementation of the curriculum and most challenges were lack of resources, lack of learning material that is variable in quality or often unavailable, under qualified teachers and inadequate training and development of teachers. This 
challenge has hindered the success of the curriculum and learners continued to receive a poor quality education. Meenakshi (2013) argued that for the success of the curriculum ICT must act as a vehicle to move OBE forward. The department of education also share the same view stating that to ensure the success of OBE curriculum information communication technology must be integrated into learning to achieve the highest possible academic standards (Meenakshi, 2013). Yet today there is still a little impact of ICT in education.

It is important to describe the concept of Information and Communication Technology (ICT) in education for the study, the researcher refers to ICT as a set of technological tools that are used to communicate. Manage (input, transmit, disseminate and output) information, this tool includes television, radio, internet, computers, social media and other computer software. The significance of these tools in education will be discussed in detail in chapter 2 of the paper. The department of education introduced computers in schools during the 1980s mainly in private schools and well-resourced government schools (Department of Education, 2003) after the introduction of OBE providing computer labs in schools become an agenda of the department of education, however, still today there is a challenge of infrastructure in schools more especially in rural areas.

Problem Analysis: Over the past four years, the Department of Basic Education has experienced a steady decline in South Africa's matric pass rate from $78.9 \%$ in 2013 to $70.2 \%$ in 2015 (DBE, 2017) whereas over $40 \%$ of the learners passed with a minimum pass rate (Pitan \& Muller, 2019b). The department of basic education reported that the reason for the decline is the lack of qualified teachers, lack of enough textbooks in schools, lack of resource, overcrowded classrooms etc. This shortcoming of school education poses a tremendous challenge in higher education because student enters into the higher education institutions academically unprepared. The centre for Education Policy Development (CEPT) that was established in 1993, to advocate and promote quality education and training for all, released an article named 'Challenges facing education in South Africa' which stated that 'South Africa has a high-cost, low-performance education system that does not compare favourably with education systems in other African countries, or in similar developing economies' (Pitan \& Muller, 2019a). The shocking article that was published in the economist, also appeared in the middle and Africa share the same sentiments revealing that $27 \%$ of South African pupils who have attended school for six years cannot read and write compared with $4 \%$ in Tanzania and $19 \%$ in Zimbabwe (Pitan \& Muller, 2019b). The department of basic education claims that many of the problem roots are from apartheid (DBE, 2016).

Pitan \& Muller (2019a) mentioned that other countries use educational software to improve the learner's reading and writing. The exposure of ICT can improve the learner's ability to read and write, for example, we can mention Malaysia which ranked 52 out of 76 subsiding South Africa at position 75 out of 76 countries in the world-class education (2015). Malaysia's quality of education has improved dramatically after they have introduced smart school, the smart school is a 'learning institution that has been systemically reinvented in terms of teaching-learning practices and school management to prepare children for the Information Age' (Agudo \& Sánchez, 2005; Haugland, 1998). ICT (Information Communication Technology) has taken the world by storm with the emergence of technology like the Internet of Things (IoT), Cloud Computing, Social Media (like Facebook, Tweeter, Instagram, LinkedIn, knowledge forums, etc.) and search engines just to mention a few. ICT is now connected and intertwined with most of our lifestyles to the extent that if a child is deprived of ICT it would be like missing an important portion of his/her early childhood development. The lack of Information Communication Technology in schools deprives learners the ability to become effective independent learners, to be initiative, creative and stay relevant in a global market.

Meaning when learners rely on teachers for information or books which might be outdated due to the everchanging market or industry; the learners learning capacity becomes limited and they grow up with limited knowledge. Limited knowledge means limited opportunities. Consequently, the purpose of this study was to determine the influence of ICT integration on the quality of teaching and learning in the classroom and also to further examine the benefits of using ICT to enhance personal growth, individual performance critical thinking skills, reading and writing skills in South Africa. The purpose statement, therefore, revolves around the following specific objectives:

- To determine whether the use of ICT in schools can improve the learner's performance.

- To determine the appropriate method of integration ICT in education. 
- To determine whether the use of ICT can improve reading and writing.

- To determine whether the use of ICT in education can improve critical thinking.

Hence, the specific questions are outlined as follows:

A. Does the use of ICT in school improve learner's performance?

- Does the use of ICT in school improve reading and writing?

- Does the use of ICT in school improve critical thinking?

B. What is the appropriate method of integrating ICT in education?

- Do you think that there are subjects that are best suited to the integration of ICT than others?

- Is it adequate for ICT to be taught as a subject rather than using ICT as a support tool for the curriculum?

Moreover, based on the specific objectives and questions, the following hypotheses were contrived from literature:

H11: The use of ICT in school can improve the learner's performance.

H12: The use of ICT as a tool to support teaching and learning can yield more benefits than teaching ICT as a subject.

H13: The appropriate use of ICT can improve learners writing and reading skills.

H14: The appropriate use of ICT can improve the thinking skills level of learners.

The above questions and hypotheses are specifically aimed at achieving the overall purpose of determining whether the integration of ICT into education can actually improve the quality of teaching and learning in the classroom and to further examine the benefits of using ICT to enhance personal growth, individual performance, critical thinking skills reading and writing skills.

\section{Review of Relevant Literature}

The Overview of the Concept of Integrating ICT in Schools: There is a major emphasis of the quality of education for all in South Africa, this emphasis of quality education served as a vehicle to redress the injustice system of apartheid, to develop a responsible citizen that contribute to the emerging democracy. However, the department of education still faces major challenges that hinder the progress of implementing quality education, especially in rural areas. On the other hand, ICT (Information Communication Technology) has taken the world by storm with the emergence of technology like the Internet of Things (IoT), Cloud Computing, Social Media (like Facebook, Tweeter, Instagram, LinkedIn, knowledge forums, etc.) and search engines just to mention a few. The concept of Information and communication technology (ICT) in this study is referred to as a set of technological tools that are used to communicate, manage (input, transmit, disseminate and output) information, the tools include television, radio, internet, computers, social media and other computer software. School is referred to as a place where teaching and learning activities take place and it is equally important to define education as it will be used frequently in this chapter, education is referred to as a set of instruction that enables the process of teaching and learning.

Many authors such as Agudo and Sánchez (2005) and Haugland (1998) agrees that the appropriate use of ICT in teaching and learning can have many more positive outcomes such as the ability to access education anywhere and anytime, it motivates learners and connects learning to the real-life situation. However, the concept of integrating ICT in school is often misinterpreted by teachers and learners as having access to information from the internet and using it to prepare school task (Pitan \& Muller, 2019a). Integrating ICT in education is not only about having computer class, teaching learners about the basic use of information technology, is about exploiting valuable services that ICT can offer to improve the pedagogy in education. Agudo and Sánchez (2005) also argue that integrating ICT into education is not only about a learner having access to information on the internet but is all about 'making learners, think of information'. Learners must get involved and be interactive with information to an extent that they can use it to be creative, identify gaps come up with new ways of doing things and new strategies to resolve some of the underlying issues experienced in the county. For this to happen the department of basic education needs to transform the learning experiences by creating a learning environment that promotes advance thinking capability through 
the effective use of information and communication technology. The last stage was launched in 1999 to carry out the second stage and transform education (Pitan \& Muller, 2019a).

Haugland (1998) claim that integration of ICT in education is not about "simple improvement of the traditional method" is about radically transforming the pedagogy in education creating collaborative learning through ICT-based learning environment. Unlike South Africa, Singapore, for example, had a master-plan of integrating ICT into the learner's assessment, pedagogy and the school curriculum which seeks to develop learner's competency for the 21st century. The master-plan included three stages, the first stage was to provide schools with ICT infrastructure and train teachers with basic knowledge of ICT, and the second stage was to create effective and persistent use of ICT in schools. This master-plan is an example of how South Africa can integrate ICT in schools. Now Singapore schools are equipped with the latest website and app to deepen student's learning and to be engaged during the classroom lesson. Some of the technologies, for example, are 3D printer technology in design and technology class, smartphone and iPad to access school assessment and projects and to continue learning even after class, iPad app to download music during music lessons and teachers also uses Facebook to generate ideas in class (Agudo \& Sánchez, 2005; Haugland, 1998). The need to integrate ICT in education has been identified as a global resolution, not only to improve the unstable economy but is also significant to all mankind (Olaofe, 2005). Mastering the basic skill of ICT has now become the basis of living because ICT has become central to the contemporary of society impacting how we do things in life. Whether doing shopping, communicating (emails, telephone, social media), financial transaction, listening to radio news or watching TV, driving a car all this includes the use of ICT. Any child who is deprived of the exposure of ICT is deprived of the basic of life. Teachers who use the behaviourism framework, they usually break down the curriculum subject content into sequence ranging from simple to more complex and the learning process becomes linear. The basic skill of ICT has now become a human right, transforming the society from Information Technology age to Knowledge age (Pitan \& Muller, 2019a; Rampersad, 2011).

The Importance of ICT in School: One of the most significant findings in the general research of the use of information communication technology in school is the ability to support inclusive practice in school. The term 'Inclusive' refers to the effort that is made in school to accommodate learners with either physical, communication, mental, or sensory disabilities. ICT can indeed assist the learners in question to overcome their communication difficulties and access a wider range of the curriculum like any other learner by providing software's that meets their particular needs that enables them to be on the same level with their peers. Example, the access device electronic communication device with recorded or synthetic speech can help learners with communication disability to improve their listening, speaking, and understanding. ICT allows learners to gather data that would be impossible to gather manually or using the traditional method. Instead of going through a dozen textbooks, magazine or newspaper to collect information, the internet provides worldwide data in a single platform. Some subjects in school are constantly changing such as social studies, health, or technology these subjects needs continuous updating to stay relevant and in use. Textbooks are the only periodical; only the use of the internet can help a student to stay up to date with the subject.

The use of ICT in school can make learners more receptive to the digital world. The exposure of ICT at an early stage can make learners to easily adapt to the new technologies and evolution. Today our lives revolve around the use of technology, from communication, shopping, cars, just to mention a few. This software's are constantly improving and widely accepted by the communities to make their lives easy. Learners need to be receptive to this communication rich-environment. ICT can help enhance the skill of teachers in their perspective areas. Many researchers indicated that one of the reasons that hinder the success of ICT in school is the unqualified teachers. With ICT teachers can access a range of forums and blogs that can improve teacher's skill and knowledge. There are also online courses that teachers can enrol and study at their own pace. Information communication technology can improve learner's thinking ability. Critical thinking is a skill that students need to be successful in their professional life; ICT is more of thinking skills than just mastering the software. ICT can provide a pedagogical framework that enables learner's to become effective independent learners; for example, computer games and other assessment software are available that can adjust themselves to the level of competency of the students and move to the next level as they improve their thinking skills. 


\section{Theoretical Review}

Constructivism Learning Theory: This theory was reinforced by educational psychologists such as Jean Piaget and William Perry after they augured their dissatisfaction with behaviourism learning theory (Rampersad, 2011). The behaviourism learning theory is teacher-centred learning, a teacher plays a significant and a led role in transmitting knowledge to learners, the students learning processes rely heavily on the teacher's material and knowledge. The assumption that is made is that student who listens to teacher's explanation, does classroom activities instructed by teachers, and engaging on the feedback provided by the teachers will result in effective learning (Rampersad, 2011). In contracts, the constructivism is learnercentred learning, constructivism learning theory suggest that 'learners must construct their knowledge and meaning of experiences' (Rampersad, 2011). This theory is concurred by researchers such as (Pitan \& Muller, 2019a; Rampersad, 2011) who are advocating the hypothesis that student learns best in an environment that enables them to discover new knowledge for themselves rather than being provided to them by the teacher. The theory encourages learners to think outside the box, be creative, learn from experiences of the world, and be active to create new knowledge. The teachers who use the constructivism framework must provide students with appropriate guidelines to assimilate new information to the existing information and encourage them to construct new knowledge by themselves.

The constructivism theory is believed to have two major benefits, firstly it enforces student to solve 'authentic,' problems. Secondly, learners can acquire new knowledge through life experiences and discipline (Agudo \& Sánchez, 2005). These benefits are based on a setting that students learn best in an environment that enables them to acquire knowledge and find a new solution for themselves. There is a strong assumption that the implementation of ICT in schools follows the constructivism theory, ICT being a force or a tool that students can use to gather new information (Haugland, 1998). The role of ICT in constructivism learning is to constitute the learner-centred learning, decrease memorization, improve the thinking capability of learners and it is only through ICT that the theory can be transformed into practice (Agudo \& Sánchez, 2005; Haugland, 1998).

Structuration Theory: The structuration theory was developed by Anthony Giddens in 1988 and has then become the most influential theoretical paradigms applied to the influence of information communication technology in education (Agudo \& Sánchez, 2005). The main argument of the theory is that it is the act of human beings that creates a new structure out of the existing structure, this means even if there is an existing structure (can be a specific tradition, culture, institution, moral codes or other established ways of doing things) individuals can reproduce or change the structure by ignoring the rules and replacing them with new behaviours (Haugland, 1998). According to the theory, information technology has the potential impact the society and reform a particular structure. Agudo and Sánchez (2005) was the first researcher to study the relationship between technology and organizational structure using the structuration theory, according to Barley's view the implementation of new technology can change an organization's structure and reform ways of doing things in an organization. The main argument of structuration theory based on the influence of information technology is that ICT has the power to reform society or a particular structure.

Empirical Review: The advantages and disadvantages of implementing ICT in school have been an interest of many researchers due to the global demand and the opinion that ICT can reduce poverty and regain the pride of mankind, so far the researchers have not yet provided a clear consensus that proves beyond doubt that ICT can improve student performance (Meenakshi, 2013; Faggella-Luby \& Deshler, 2008). Since the revolution of the internet, many researchers shifted focus to the use of internet activities in school such as the blog, Wikipedia, social media and other online platforms; hence thus far there is still no concrete proof of how ICT can improve student performance. It is importable that we take the topic seriously because ICT has extremely influenced every discipline under the sun and education cannot be an exception (Meenakshi, 2013; FaggellaLuby \& Deshler, 2008). Brush, Glazewski, and Hew (2008) have augured that ICT can be used as a tool for students to discover new information, Improve their problem-solving techniques and come up with new solutions in both their communities and in the classroom. Meenakshi (2013) stated that ICT can provide the ability of students to become the lead on their learning process by learning to manipulate information and building new knowledge through the access of internet. ICT provides many possible ways that can improve student's understanding, for example, e-books are commonly used in aloud activities, this can be beneficial to 
a learner who struggles to read the text and this e-book can be accessed using a device such as a laptop, iPad, cell phone or a computer. Another example is the use of images to explain a learning topic; ICT can present different images in a different format to attract a learner's interest.

Rampersad (2011) augured that ICT provides lots of service to learner's including 'distance education programmes, inexpensive printing, cell phone plans, internet connection, free dial-up, technology equipment, rentals classroom media stations, etc.' Rampersad (2011) further insisted that computer brings powerful aids of translating theory into education, he mentioned computer assistant learning and distance education for examples. Koc (2011) mentioned that the use of ICT in the learning environment can promote collaborative learning enabling students to communicate effectively and share work anywhere, anytime. For instance, the use of blogs and Skype can gather students around the world to collaborate, share knowledge, explore ideas and solve the major problem. The study of Meenakshi (2013) indicated statistically that there is a correlation of using ICT to learn and the acquisition of critical thinking skills. Many authors shared the same sentiments indicating that the integration of ICT into education can foster the students to reach a higher level of thinking skills. Barak and Dori (2009) explain critical thinking as a skill that requires a student to think independently, rationally and clearly to take responsibility and control one's mind. Barak and Dori (2009) further explain that critical thinking is essential for one to have to be successful in the future. Through the implementation of ICT in school students can access educational software such as games to improve their thinking skills the disadvantage of integrating ICT into education is limited; the one which was the most concern.

Quality use ICT to Improve Learning and Teaching: Researcher mentions the keyword 'appropriate' when they justify the benefits of integrating ICT in teaching and learning, there is no single evidence indicating that teaching and learning can be improved by just using computers. Significantly, we understand the appropriate use of ICT to improve the quality of education in South Africa. Rampersad (2011) argued that we need to integrate ICT in schools in such a way that it allows learners to take control of their learning than the subject content itself (Pitan \& Muller, 2019a; Rampersad, 2011). Social media (Facebook, Twitter, Instagram etc.) can be addictive, destructive and can shift a learner's focus. When a learner's focus is shifted the purpose of integrating ICT in education is going to be defeated. The more the learners become capable of learning by themselves or with their peers, there more their thinking skills improves. Rampersad (2011) mentioned that is also important that ICT allows teachers to create their materials and provide more control of the course content. One of the countries that were recognized to have been deemed to have made reasonable progress in integrating ICT in education in Singapore.

Singapore had a master-plan of integrating ICT into the learner's assessment, pedagogy and the school curriculum which seeks to develop learner's competency for the 21st century. The master-plan included three stages, the first stage was to provide schools with ICT infrastructure and train teachers with basic knowledge of ICT, and the second stage was to create effective and persistent use of ICT in schools. The last stage was launched in 1999 to carry out the second stage and transform education (Pitan \& Muller, 2019b). This master-plan is an example of how South Africa can integrate ICT in schools. Through the initiation of the master plan, leaners were able to develop competencies for independent, collaborative learning and also become responsible ICT users. The integration of ICT in education needs to be designed in a way that it revitalizes both learners and teachers, develop the quality of education by providing support in difficult subject areas (Pitan \& Muller, 2019a). South Africa needs to change and reform its education system and use ICT as a vehicle to improve the quality of education.

Information Age: "People whose education consists of lectures and textbooks are not well prepared for problem-solving in the complex world that we live in" Patricia Senn Breivik. There is a common say that said 'we are living in an information age' that is true; ICT has brought information on our fingerprint. The information age is referred to as a modern time in which information is easily accessible, disseminated, stored and managed through the use of computers. In the information age, students should be able to construct knowledge, instead of a teacher handing it to them (Rampersad, 2011), creating an opportunity for students to teach and learn from each other. The importance of integrating ICT in education is to enable student and learners to acquire knowledge deem relevant in the information age (Rampersad, 2011). 
The Current State of ICT in South Africa and Education: According to world economic Forum data (WEF) network readiness index (NRI), South Africa ranks 75 out of 143 countries in the year 2015 (WEF, 2015). The WEF NRI report measures the exploitation, opportunities, and the influence of ICT in a competitive world (Pitan \& Muller, 2019a; Rampersad, 2011). The WEF NRI statistics indicate that South Africa also lags with its fellow BRICS countries, Brazil ranking (60th), Russia leading them with (54th), India (68th), and China (58th) (WEF, 2015). The report that was published by UNESCO Institution for Statistics titled, Information and Communication Technology (ICT) in Education in Sub-Saharan Africa - A Comparative Analysis of Basic EReadiness in Schools which explains what is happening in the African continent regarding ICT implementation in education, the report mention South Africa as one of the African continent country that has ICT policies and plans in place to implement ICT in education (Pitan \& Muller, 2019b), however, even today there is still the little impact of e-learning in the South African education (Shafika, 2007). As with the status, in 2015 the status of schools with computer facility is 40.9 per cent (DBE, 2015) this includes schools that have one or more computers for administration purpose. The report of the South African Institution of Race and Relation (SAIRR) states that 4 out of 10 public schools have computer facilities (Pitan \& Muller, 2019a).

The Political Influence of ICT in Education: The political goal of providing quality education to all has a significant influence on implementing ICT in education. For political agenda education is necessary for four reasons, firstly, it reduces poverty, contributes to the economy and the national development of the country. Secondly, it is seen as the only way that an African child can regain his pride that was diminished during the apartheid era. It is without a doubt that the exploitation and opportunities offered by ICT in South Africa affect the implementation of ICT in schools. The fact that South Africa ranks 75 of 143 countries in the WEF, network readiness index Report indicates the lack of positive impact in South African e-education learning. Thirdly, education can reduce corruption and lastly, education amongst women can decrease maternal mortality rate, in turn, the country's population will decrease and the government services will be able more effective than efficient (Meenakshi, 2013; Faggella-Luby \& Deshler, 2008). The National Integrated ICT Policy White Paper that was released on 28 September 2016 (White paper, 2016) after the government had realised that social, political and economic transformation has certainly changed and ICT policies need to respond to the change (Rampersad, 2011). In 2012 the South African cabinet initiated the review of ICT related policies.

They appointed a panel which included the representatives from the private sector, public sector, stateowned companies, NGOs and academia in January 2013 to assess the policy, diagnose the challenges and recommend proactive policy approach for future reference (Meenakshi, 2013). The development of the National Integrated ICT Policy was based on the outcome of the panel's findings and recommendation. Meenakshi (2013) explained that the review of the ICT related policies was necessary to address the current ICT challenges in the country. The political analyst (Rampersad, 2011) said that ICT can have a great impact when policies designed to implement them are crafted in a manner that supports the transformation of education. In 2010, the government introduced new Growth Path which stated a route map to create new skills and jobs to eradicate poverty and in 2013 the document was updated and renamed the National Development Plan (NDP). The NDP (2013) stated poor quality of education in of one of the challenges in the country and the document further recommended E-learning as a mechanism that can be used to redress the inequality in education and provide continuous improvement in education (NDP, 2013). The national Development plan serves several important functions such as providing a vision of how ICT can be implemented in schools and how the learners, teachers, parents and the public can benefit from its use in schools (Pitan \& Muller, 2019a; Rampersad, 2011).

Gaps in the Literature: The advantages and disadvantages of implementing ICT in school have been an interest of many researchers due to the global demand and the opinion that ICT can reduce poverty and regain the pride of mankind, so far previous studies have not yet provided a clear consensus that proves beyond doubt that ICT can improve student performance (Rampersad, 2011). Rampersad (2011) mentioned that the development of ICT policies is essential because it encourages government and organization to initiate programs resource and enable efficient use of ICT in schools. Since the revolution of the internet, many researchers shifted focus to the use of internet activities in school such as the blog, Wikipedia, social media and other online platforms; hence thus far there is still no concrete proof of how ICT can improve student performance. We must take the topic seriously because ICT has extremely influenced every discipline under the sun and education cannot be an exception (Pitan \& Muller, 2019a; Rampersad, 2011). 


\section{Methodology}

The research design is a significant part of the research because it plans how the research will be conducted and implemented to obtain answers. The study follows the qualitative research design. Awolusi (2019) state that the research design aims to plan and align the research objectives with the practical consideration and limitations (Oladejo \& Awolusi, 2018; Eze \& Awolusi, 2018). The research approach is 'Action Research'. Corey (1953) define action research as an attempt of a fellowing colleague or a researcher to study an underlying problem scientifically to correct, provide guides or and evaluate actions. This approach is suited for the present study since action research can combine theory and practise, providing the ability to focus on generating solutions and empower both the teachers and the learners (Awolusi, 2019). The interest of action research in education is growing rapidly because it encourages teachers to work together on a common issue, provide an opportunity to learn, correct their mistakes and improve their teaching practice (Awolusi \& Atiku, 2019).

Research Method: In this study, the researcher follows 'Qualitative Method'. Qualitative research is design to reveal a different range of behaviour and the perception that a specific target audience has on the identified topics or challenges (Awolusi et al., 2018; Burns and Grove, 2000:388). In this study, we use a qualitative method to understand what is happening inside the classroom and analyse the effect of the situation or other educational intervention. The researcher attempted to keep the research question narrow in the scope. The researcher started by analysing what exactly needs to be resolved or improved and drafted all the possible points. All question were evaluated to ensure that there relate directly to the research topic. The research questions were semi-structured and open-ended.

Population and Sampling: A well-defined sampling strategy is important in qualitative research to; attain unbiased and robust research result (Awolusi, 2019). There is a tendency of considering qualitative sampling design as less important comparing to quantitative sampling and most qualitative researcher makes little attempt to ensure that sampling is an accurate reflection of the population (Polit and Hungler, 1995:517). Conscious selection of population group by the researcher was considered in the study. The research sample was compromised in two groups namely, the teachers and the learners. The reason why the researcher interviewed both the teachers and the learners is to understand and compare the classroom experience from both the learners and teachers. The two groups participated in the same criteria setting and answer the same questions (see Appendix A). The sampling criteria are significant to standardize the population as possible (De Vos, 1988:193). In this study the sample criteria were as follows: Participants must speak Sepedi or English; must be over 18; must be either a high school teacher or a high school learner; and all races must be included in the sample. There were only nine (9) learners that are above eighteen (18) at Derek Kobe Secondary School and all nine learners participated in this study. Seven (7) teachers volunteered to participate; the total number of informants was sixteen (16).

Data Collection and Analysis: In this study, data will be gathered using focus group interviews, questionnaires and observation. Next, the researcher will elaborate on the three selected method and the objectives of each method.

Focus Group: A focus group is defined as a group of selected individuals having common interest or character and asked about their opinion or perspective about an issue or a topic (Pitan \& Muller, 2019a; Rampersad, 2011). The main advantage of the focus group interview is the ability to obtain data more quickly from many individuals at a lower cost and short period (Rampersad, 2011). The focus group interview was held at Derek Kobe Secondary School, the first group consisted of teachers and the second group consisted of learners. The interview environment was conducive, comfortable and a non-threatening for all participants. The period of the interview is an hour long. The researcher requested permission to record the interview session before the sessions and later the researcher transcribed and translated verbatim.

Questionnaire: The researcher made a provision for individuals who cannot make it to the interview session but wish to participate. The questions on the questionnaire were similar to interview questions asked in the focus group. All processes and criteria were similar to the focus group interview except that the fact that the informants were only participating at their own space and their own time. 
Observation: The researcher visited Derek Kobe Secondary School for a day; the aim was to observe their ways of teaching and learning, routines and participation and collaboration of students in the classroom. The observation method will help the researcher to have access to a real-life situation.

\section{The Process of Data Analysis}

- Following Creswell' approach, the researcher started by organising and preparing data for analysis, using listening to the audiotapes of the interview repeatedly to internalise the context and then transcribed the interview. The read through the data and ensure that no data was left out.

- After completing the task for all focus group interviews the researcher read through the data again to make general sense of the information and get the overall meaning of the data. The researcher created categories of information.

- The researcher broke down the data into a chunk of information and each chunk of information fell under an identified topic.

- Lastly, the researcher presented the findings and analysis in the next chapter.

To ensure that adequate ethical guideline and standards are adhering to in this study, all participants received and signed a consent form (see appendix B) before participating in the data collection. The consent to access the school and interview learners and teachers was requested and approved by the department of basic education (see appendix C).

\section{Data Presentation, Results and Discussion of Findings}

The purpose of the proposed study was to determine, analyse and understand how the integration of ICT, into education can help solve challenges related to poor quality education and how ICT can improve the overall quality of education in South Africa. All participants were asked to express their thoughts, ideas and experiences about the integration of ICT in education. The objectives of the study were as follows:

- To determine whether the use of ICT in schools can improve the learner's performance.

- To recommend the appropriate method of integration ICT in education.

- To determine whether the use of ICT can improve reading and writing.

- To determine whether the use of ICT in education can improve critical thinking.

Data was collected using a focused group interview; the focused group were divided into two groups. The first group consisted of nine grade 12 learners and the last group was seven teachers. All participants were asked six open-ended interviews which were as follows:

- How can ICT help you achieve your work (teaching or learning) more effectively?

- Do you think that the use of ICT in school can improve reading and writing and why?

- Do you think the use of ICT in school can improve learner's thinking and why?

- How do you think ICT should be used in school?

- Do you think some subjected are better suited with ICT than others and why?

- Is it adequate for ICT to be taught as a subject rather than using ICT as a support tool for the curriculum?

The Process of Data Analysis: Data were analysed using Creswell' approach of qualitative data analysis (Tapscott, 1998; Fredrickson, 1981); the researcher listened to the audiotapes repeatedly to internalize the context and transcribe the interview verbatim. The researcher read and re-read the verbatim transcripts to get the general sense of information and the overall meaning of the data. The researcher started identifying and grouping similar topics and ideas, new themes emerged during the data coding. The participants were also asked to validate the process of data analysis.

Themes: The themes were group according to teachers versus students. We have separated the two categories because during data analysis the researcher realized that even though both the participants (teachers and students) has been asked similar questions, their answers, ideas and perspectives were different. Under each group (teacher and learners) the researcher has written sub-themes and their category. The researcher will first tabulate the themes and then describe each theme below. Within the tables, the 
researcher quote words of the participants to indicate the emotions they set when expressing their thoughts towards the integration of ICT in education.

\begin{tabular}{ll}
\hline Category & Themes \\
\hline Learner's perceptive & Reading and writing in the classroom \\
& Language proficiency \\
& Teaching methods \\
& The possibility of online learning \\
& Teaching subjects using ICT \\
Teacher's perspective & Teachers expertise and confidence in using ICT \\
& Skills development \\
\hline
\end{tabular}

Learner's Perceptive: Theme One: Reading and writing in the classroom many students shared frustration about the shortage of textbooks at school. All participants indicated major challenges that negatively impact their ability to read and write effectively. Some of the challenges mentioned were: the shortage of textbooks and stationery, absence of teachers in the classroom, lack of mentorship, and shortage of qualified teachers. Below are some of the learner's remarks.

\begin{tabular}{|c|c|}
\hline Record ID/Date/Speaker/Session & Quotation \\
\hline 342/15-01-2018/Anonymous /2 & $\begin{array}{l}\text { "We do not have textbooks, year after year when we start a new grade; } \\
\text { the teachers tell us that the previous students did not bring back their } \\
\text { textbooks. The teachers write notes on the chock board, and we copy } \\
\text { them to our scribe books but sometimes this scribe books get lost and } \\
\text { then you're in trouble." }\end{array}$ \\
\hline 348/15-01-2018/Anonymous /2 & $\begin{array}{l}\text { "We usually memorize word by word because if you write anything } \\
\text { that is not in the teacher's notes, you are going to fail. We don't study } \\
\text { to understand, we study to pass." }\end{array}$ \\
\hline 339/15-01-2018/Anonymous /1 & $\begin{array}{l}\text { "I remember one year, we spend almost two months without a } \\
\text { geography teacher and finally the teacher comes, he could not answer } \\
\text { most of our questions." }\end{array}$ \\
\hline
\end{tabular}

The recent study of Gordon concluded that 'Students that can't read effectively fail to grasp important concepts, score poorly on a test and ultimately fail to meet educational milestones' (Tapscott, 1998; Fredrickson, 1981). One of the learners mentioned that most of the classrooms have 'more than 60 learners, which makes it even more difficult to concentrate in classes.

Theme Two: Language proficiency all participants indicated that teachers sometimes teach English (second language) in their mother tongue (first language) to make learners understand but this translation does not assist much because during the test they must write in English. Below are some of the student remarks.

\begin{tabular}{ll}
\hline $\begin{array}{l}\text { Record } \\
\text { ID/Date/Speaker/Session }\end{array}$ & Quotation \\
\hline $348 / 15-01-2018 /$ Anonymous /2 & 'I was taught English in Sepedi (mother tongue) ever since'. \\
339/15-01-2018/Anonymous /1 & $\begin{array}{l}\text { 'I know it is important to know English because all other subjects are } \\
\text { written in English. I just wish we had a platform where we practice } \\
\text { English on our free periods' }\end{array}$ \\
\hline
\end{tabular}

According to section 29(2) of the Constitution states that 'every learner has the right to receive a basic education in the language of his or her choice, where this is reasonably practised' (Pitan \& Muller, 2019a; Rampersad, 2011); the use of African languages at school was another vehicle to depart from the history of apartheid. However, According to DOE, a learner will not be promoted if the learner scored below the pass rate in any language, this includes English. All participates complaint that as much as their given instruction in their mother tongue, they should also be allowed to write in their mother tongue or maybe they should have a platform was learners can learn English proficiency on their own pace. 
Theme Three: Teaching methods all participants confirmed that the method of teaching method is teachercentred learning, the learners rely heavily on the teacher's knowledge. The following are some of the comments from learners.

\begin{tabular}{|c|c|}
\hline $\begin{array}{l}\text { Record } \\
\text { ID/Date/Speaker/Session }\end{array}$ & Quotations \\
\hline 334/15-01-2018/Anonymous /1 & $\begin{array}{l}\text { 'To be honest, I sometimes do not hear anything in the classroom; the } \\
\text { teacher will come and talk! Talk! Talk! The whole period. I think it } \\
\text { would be more helpful if we had tutors'. }\end{array}$ \\
\hline 336/15-01-2018/Anonymous /1 & $\begin{array}{l}\text { 'We do not usually do group discussion, although we try to help each } \\
\text { other with homework'. }\end{array}$ \\
\hline 339/15-01-2018/Anonymous /1 & $\begin{array}{l}\text { 'The teacher writes notes on the board and we copy to our excise book } \\
\text { and then we refer to our notes when we write homework'. }\end{array}$ \\
\hline
\end{tabular}

Eight (8) of ten (9) learners indicated that they do not like the current method of teaching because it does not groom leaners to become independent and to be future leaders, instead it teaches learners to be lazy. One of the learners said that 'the truth is that, we are spoon fitted' and the learner revealed frustration.

Theme Four: The possibilities of online learning all participants revealed excitements about the idea of integrating ICT in education. Below were their comments.

\begin{tabular}{ll}
\hline Record ID/Date/Speaker/Session & Quotations \\
\hline $339 / 15-01-2018 /$ Anonymous $/ 1$ & $\begin{array}{l}\text { 'School will be exciting but seriously it will solve most of our } \\
\text { challenges, for example, if the teacher is absent from class, we can } \\
\text { go to the lab and do research '. }\end{array}$ \\
'It will be nice to have a platform where you can download \\
questions and answers, interact with peers and learn the basic \\
skill of ICT.'
\end{tabular}

All participants indicated a positive attitude toward the integration of ICT in the classroom. The participants mentioned a few points that ICT can assist them to learn effectively. 1). Access of e-books 2). Online assessment 3). Active interaction with peers from local school 4). Provide basic skills in ICT for market relevancy.

Teaching Subjects Using ICT: The reluctance to use ICT was evidence during the teacher's interview; perhaps this was because the teachers are afraid of change and lacked experience in ICT. Teachers were very much uncomfortable about the teaching of subjects using ICT. Below are their expressions:

\begin{tabular}{ll}
\hline Record ID/Date/Speaker/Session & Quotation \\
\hline 220/12-01-2018/Anonymous /2 & $\begin{array}{l}\text { 'How do you expect teachers in my age to start learning ICT, I know } \\
\text { my job, I have been teaching life science for 15 years and my } \\
\text { students are passing. I don't need to know ICT' } \\
\text { 'Some subjects like mathematics and physical science cannot be } \\
\text { integrated with ICT'. }\end{array}$ \\
$\begin{array}{l}\text { 'I don't think we do have a framework for the integration of ICT in } \\
\text { the classroom ........ That is where the problem starts....... We are } \\
\text { confused.' }\end{array}$ \\
\hline
\end{tabular}

Many teachers are still confused about how ICT can be integrated into school subjects. This is the similar finding of Leonard Newton, in his research study titled 'Management and the use of ICT in subject teaching', the research evidence that teachers often have the pressure of integrating ICT in their lesson with no proper guidelines of how and where ICT fits in their teaching framework (Pitan \& Muller, 2019a; Rampersad, 2011). The teachers of Derek Kobe senior secondary school did not understand how ICT will fit into the school 
curriculum; they vision ICT as a support tool for the administration process at school. They emphasised that ICT can help solve issues such as lack of storage, linkage of question papers, the record of learner's reports and school performance but showed a little concern about ICT in the classroom. Mathematics and physical science teacher were worried that computers will solve problems on behalf of the learners.

Teacher Expertise and Confidence in Using ICT: Teachers understood that the integration of ICT in education can be beneficial in some ways but yet lacked confident about the possibility of government investing in ICT and empowering teachers. Below are the teacher's comments.

\begin{tabular}{ll}
\hline Record ID/Date/Speaker/Session & Quotations \\
\hline $222 / 12-01-2018 /$ Anonymous $/ 2$ & $\begin{array}{l}\text { 'We are struggling to get just one desktop .... How can the } \\
\text { government invest in expensive software and hardware, if we } \\
\text { cannot get simple tools like a desktop?' } \\
\text { 'I know that integration can be good for both teachers and learners, } \\
\text { there are a lot of online platforms that can teach the learners how } \\
\text { to read and write. Teachers can also collaborate online' } \\
\text { 'We have an online WhatsApp group, we mainly use it for internal } \\
\text { communication and it is much helpful. The introduction of ICT can } \\
\text { help in many ways'. }\end{array}$ \\
\hline
\end{tabular}

Young teachers from the age of 30 and less responded with so much confidence about the use of ICT in the classroom, however, with the provision of proper training, support from ICT specialist and management. Whereas, teachers above 40 showed a lack of confidence and interest in the integration of ICT in the classroom. One of the teachers said that 'I fear that we are going to become part of the furnisher while young people take your jobs', the teacher worked at the same school for more than 30 years, started as a cleaner until promoted and she is now teaching home language (Sepedi), she expressed a deep sense of fear for losing her job. Some teachers do not want to go back to school and study; they explained that they are 'too old for that'. The research that was published at the University of Cape Town stated that South Africa tends to hire unqualified or under-qualified teachers (Pitan \& Muller, 2019a).

Skills Development: Teacher's ICT skills and development is advised worldwide. Rampersad (2011) viewed teacher's training and skills as the main catalyst to the success of the integration of ICT into learning and teaching. However, teachers insisted that management does not take training and skills development seriously. Below are the teacher's experiences about skills development in their perceptive areas.

\begin{tabular}{ll}
\hline $\begin{array}{l}\text { Record } \\
\text { ID/Date/Speaker/Session }\end{array}$ & Quotation \\
\hline 220/12-01-2018/Anonymous /2 & $\begin{array}{l}\text { 'I come here seven years ago and I have not gone to any professional } \\
\text { training for personal development. It's not that I have not initiated but } \\
\text { the very attempt I am always told that there is no budget } \\
\text { 'There is no growth in teaching, I regret the day I choose this career, } \\
\text { and we are not taken seriously. We have to fight for everything } \\
\text { including teaching materials'. }\end{array}$ \\
\hline
\end{tabular}

Teachers stressed that skills development is not something that is often practised, according to them, skills training fails due to a few factors. One major factor is the shortage of teachers, there are usually allowed to stay away from the classroom for a longer period. From all seven teachers who disclosed their qualifications, only 3 of them have degrees and the others have a college certificate. SADTU conducted a study and interviewed ninety-one teachers about their professional development and training, the finding indicated that eighty-five teachers received their first training at different colleges in South Africa and only six teachers received their fundamental training at the universities (Pitan \& Muller, 2019a).

Classroom Observation: The researcher went to school to try to find out the behaviour and practices of learners and teachers in the classroom. The observation aimed to see how the current classroom situation is 
and how the integration of ICT in the classroom can assist to transform the classroom experience. The researcher aims to understand if the current teaching methods are learner-centred setting or teacher-centred setting; the observation was composed of three dimensions. The dimensions were: (1) Communication, (2) Real-life experience link, (3) Questioning/participation.

Communication: This dimension aimed to analyse the communication between the teacher and learners in the classroom, to verify if the communication is from teacher to learner, leaners to teachers or if there is a peer to peer communication. To achieve this, the researcher observed how the teacher conducted the classroom activities such as problem-solving, classroom excise and homework corrections.

Findings: The communication was mostly teacher to learners. Each subject is allocated an hour; the researcher observed that the teacher spoke for approximately fifty minutes of the lesson. The teacher explained notes, demonstrated diagrams on the board and the leaners listened without any interruptions.

Real-Life Experience Link: This demission aimed to verify if teachers bring the real situation in the classroom and the learners can relate the classroom activities with what is happening outside the classroom.

Findings: During the mathematical classroom, there was no linkage of a real-life situation and the classroom, however, during life orientation, students were very much active and bought life situations into the classroom.

Questioning/Participation: This dimension aimed to find out if teachers provide an opportunity for the learners to ask questions, allow other learners to answer and to also analyse how learners construct their questions and answers.

Findings: The teacher gives a platform for leaners to ask questions but only one leaner out of 58 leaners asked a question. In general, participation was poor.

\section{Summary, Conclusion and Recommendations}

Summary: Many research studies have revealed that Information Communication Technology (ICT) can be a significant tool to improve the quality of teaching and learning in the classroom. The most crucial point derived from the literature review is that ICT has proven to be effective across the whole curriculum not just for mathematics and science. While some teacher still fears the use of ICT in the classroom, learners show great interest and enthusiasm to use ICT. ICT does not only enforce rules and regulation but it is also flexible, it allows changes in the organization or curriculum at any point in time. It also encourages teamwork, collaboration and improves computer literacy for both teachers and learners. According to the literature review, there is no doubt that ICT has a positive academic impact on learners with special needs. According to the participants, there is still a lot to be done by the government to initiate the process of integrating ICT in education or empower teachers with ICT skill and to do away with the traditional teaching method.

The literature review reveals that for a successful implementation of ICT in the classroom teachers training is significant as they become the main catalyst of the integration. The participants complained about the school budget constraint for skills training and procurements of teaching and learning resource. Much previous research such as Pitan and Muller (2019a) and Rampersad (2011) indicated that buying desktop and laptop is not enough, budget for ICT at schools should include software, hardware, maintenance, support services, and proper development of infrastructure.

Conclusion: The study revealed strong arguments about the integration of ICT in education to improve teaching and learning practices. Following the objective of the government to transform South Africa into an inclusive and innovative digital and knowledgeable society, the government has made progress to implement policies that reinforce and facilitate the implementation of ICT in education. Below are some of the documented findings:

- The literature review provides evidence that a proper integration of ICT in education can improve teaching and learning. 
- Evidence showed that information technology in the classroom can improve learner engagement and concentration.

- ICT can provide a pedagogical framework that enables learner's to become effective independent learners. For example, computer games and other assessment software are available that can adjust themselves to the level of competency of the students and move to the next level as they improve their thinking skills.

- The integration of ICT into education can foster the students to reach a higher level of thinking skills.

- ICT enables educational activities that are hard to achieve with traditional leaning such as discovery learning.

- ICT enables access to reading material such as E-books.

The finding of the interviews leads us to document that the department of education still has not yet achieved the milestone of providing quality education for all. Below are the summaries of the finding of this research.

- There is a considerable shortage of books

- Learners are frustrated about the teaching method

- Learners feel like they are not taught to understand the basic concept but to memorize teacher's notes.

- The department still hired under-qualified teachers

- There is a shortage of teaching tools such as paper, stationery, textbooks

- Teachers fear change, whereas learners show excitement

The study, therefore, concludes that the integration of ICT in school will have a positive influence on both teachers and learners. The implementation of ICT in the classroom will improve the quality of teaching and learning, the relationship between teachers and the learners, encourages peer to peer learning, discovery learning, teamwork, critical thinking, computer skills and the overall student performance.

Recommendations: The implementation of ICT in the classroom will improve the quality of teaching and learning, the relationship between teachers and the learners, encourages peer to peer learning, discovery learning, teamwork, critical thinking, computer skills and the overall student performance. Consequently, the following specific recommendations are desirable:

- The teachers training to use ICT is significant to the implementation of ICT in the classroom, a welltrained teacher can provide creative ways to enhance learners understanding, provide an individualized option for students to learn at their own pace and prepare learners for future technology change in the society and higher education.

- The government must provide training incentives to encourage personal development in teachers and for young graduates to value teaching.

- It is crucial and needs careful consideration when choosing the right technology for the integration of ICT in schools.

- The budget planner must work on the total cost-benefit equation and ensure that investment matches the teacher's support services, resource, effective use of technology and policies. Learners need to be provided with minimum acceptance ICT resources; this includes (Internet, Security measure, computer, school software etc.).

- Policies about lost equipment must be drafted and understood by all parties.

- Technology innovation such as E-learning, blogs can assist the department of education to address the inequalities in education and facilitates ongoing improvements for both teachers and learners. The study further suggests that the implementation of ICT into education follow the recommendation of UNESCO (UNESCO, 2002) on the four stages of ICT integration. The four stages are as follows:

- 'Emerging'. This is the initial stage where the school initiate the procurement of computer equipment and software, in this stage teachers and school managers are starting to familiarise themselves with the possibilities of using ICT to improve the quality of education.

- 'Applying'. In the second stage, teachers become dominant in a sense that they need to assist learners to develop an understanding of the contribution of ICT into their learning activities and create a task that will enable them to use the information skills. 
- 'Infusing'. In this third stage, the integrations of ICT I school starts to involve across the whole curriculum. Learners will start having an intense understating of the contribution of ICT into learning and teaching. Learning software and online assessment will be embedded in subjects area and teachers start exploring new ways of using ICT.

- 'Transforming'. In the transformation stage, learners use ICT rethink and become creative. The ICT becomes an integral part of the school's development and knowledge and the school becomes the learning centre of the entire community.

Implications and Contributions to Knowledge: Being action research and qualitative study, the present study serves as a veritable 'tool' of responding to the major challenges that hinder the progress of implementing quality education, especially in the rural areas in South Africa. In addition to its major contributions to practice, the present study is also an extension to the on-going debate on ICT integration in education in South Africa. The adopted theories and conceptualisation also validate the influence of ICT integration on the quality of teaching and learning and the overall benefits of using ICT to enhance personal growth, individual performance, critical thinking skills reading and writing skills. The implementation of ICT in education continues to pose challenges both locally and globally. The white paper on E-education states main challenges as to be the transformation of the information society, the impact of ICT access, financial implication, and the process of integrating ICT into learning and teaching (DOE, 2003: 8). Consequently, the present study demonstrates how ICT can be used to improve learners thinking skills, writing skills, and empower them to become independent learners, as well as, the veritable roles of teachers as formidable catalyst of integrating ICT into education. The study, therefore, suggest, that teachers and learners must use computers to learn rather than learning how to use computers or have a computer as a subject.

This study also provides a clear indication of how ICT integration in education can improve the quality of education and resolve some of the major issues faced by the department of education. There are many ways of adding value to the integration of ICT in education. For instance, the UNESCO report states that ICT skills must not be 'taught as a distinct activity 'but be learnt in a context that is meaningful to both the teachers and the learners (Pitan \& Muller, 2019a; Roos, 2005). The success of the integration of ICT into education lies in the ability of the teachers to create activities and task that will enable learners to use the information skills effectively. This approach is encouraged by the new teaching strategy in South Africa called Outcome-Based Education (OBE) and learner centred learning (Roos, 2005). Although, the study is more of scholarpractitioner/ action research, however, the study and data collection were carried out in one school in Limpopo province, hence, there is need to be cautious in generalising the outcomes of the study. Future studies may extend the investigation to other provinces. That notwithstanding, the study validated all survey instruments and objectively investigated the influence of Information Communication Technology (ICT) in improving the quality of education in South Africa. Lastly, the study also posits that teachers are the catalyst for integrating ICT into education. Further studies may determine to which extent does the teacher and learners need to use computers to co-construct knowledge and collaborate in school projects.

\section{References}

Asika, N. \& Awolusi, O. D. (2013). Modelling Critical Success Factors of Business Process Re-Engineering and Business Performance of Nigerian Oil and Gas Companies, International Journal of Services and Operations Management, 15(1), 28-43.

Asikhia, U. O. \& Awolusi, O. D. (2015). Assessment of Critical Success Factors of Business Process Reengineering in the Nigerian Oil and Gas Industry, South African Journal of Business Management, $46(2), 1-14$.

Asrar-ul-Haq, M. \& Kuchinke, K. P. (2016). Impact of leadership styles on employees' attitude towards their leader and performance: Empirical evidence from Pakistani banks, Future Business Journal, 2(1), 5464.

Awolusi, O. D. (2013a). Effects of motivation on employee job commitment in the Nigerian banking industry: an empirical analysis, International Journal of Business and Innovation Research, 1(3), 1-17.

Awolusi, 0. D. (2013b). The effects of total quality management on customer service management in the Nigerian banking industry: an empirical analysis, International Journal of Management and Network Economics, 3(1), 57-77. 
Awolusi, O. D., Mbonigaba, J. \& Tipoy, C. K. (2018). Mineral resources endowment and economic growth in Southern African countries, International Journal of Diplomacy and Economy, 4(1), 59-79.

Awolusi, O. D. \& Atiku, O. S. (2019). Business Process Re-Engineering and Profitability in the Nigerian Oil and Gas Industry: The Mediating Influence of Operational Performance, Information Management and Business Review, 11(3), 13-26.

Awolusi, O. D. (2019). Human Capital Development and Economic Growth in BRICS Countries: Controlling for Country Differences, Journal of Economics and Behavioral Studies, 11(4), 1-17.

Agudo, J. E. \& Sánchez H. (2005). Development and implantation of an adaptive hypermedia system for young learners. Euro-call Conference. Cracow, Poland.

Archer, J. (2014). The Outcome-Based Curriculum Initiatives.

Barak, M. \& Dori, Y. J. (2009). Enhancing higher-order thinking skills among in-service science teachers via embedded assessment. Journal of Science Teacher Education, 20(1), 459-474.

Brush, T., Glazewski, K. D. \& Hew, K. F. (2008). Development of an instrument to measure preservice teachers' technology skills, technology beliefs, and technology barriers. Computers in the Schools, 25(1), 112125.

Burns, N. \& Grove, S. K. (2000). The practise of nursing research: Conduct, critique \& utilization. 4th edition. Philadelphia: WB Saunders.

Corey, S. M. (1953). Action research to improve school practice'. New York: Teachers college, Columbia University.

Department of Education. (2003). White Paper on e-Education. Transforming Learning and Teaching through Information and Communication Technologies'. Pretoria: Department of Education.

De Vos, A. S. (1998). Research at grassroots. 1st edition. Pretoria: JL van SchaikChisholm, L. (2003). The Politics of Curriculum Review and Revision in South Africa.

Department of Basic Education (DBE) Republic of South Africa. (2010). Delivery agreement for outcome.

DBE Republic of South Africa. (2011a). NEIMS (National Education Infrastructure Management System) reports May 2011.

DBE Republic of South Africa. (2011b). Report on the Annual National Assessments of 2011.

Eze, T. O. \& Awolusi, O. D. (2018). Effect of Critical Factors on Expatriate Assignment Performance in the Nigerian Oil and Gas Sector, Global Journal of Interdisciplinary Social Sciences, 7(2), 6-19.

Faggella-Luby, M. \& Deshler, D. (2008). Reading comprehension in adolescents with LD: What we know; what we need to learn, in Learning Disabilities Research and Practice, 23(2), 70-78.

Fredrickson, G. M. (1981). White Supremacy. New York, New York: Oxford University Press.

Jansen, J. D. (1998). Essential alterations? A critical analysis of the states syllabus revision process, Perspectives in Education, 17(2), 1-11.

Hartshorne, K. B. (1992). Crisis and Challenge: Black Education 1910-1990. Cape Town: New York: Oxford University Press, 1992.

Haugland, S. W. (1998). The best development software for young children. Early childhood education journal, 25(1), 247-254.

Kallaway, P. (1984). Apartheid and Education: The Education of Black South Africans. Johannesburg: Ravan Press, 1984.

Koc, M. (2011). Implications of learning theories for effective technology integration and preservice teacher training: A critical literature review, Journal of Turkish Science Education, 2(1), 2-18.

Meenakshi, P. G. (2013). Importance of ICT in Education. Journal of Research \& Method in Education, 1(2), 468493.

Olaofe, I. A. (2005). Nigerian educational emancipation: a roadmap from crisis to resurgence. Faculty of Education Seminar Series, No. 1. Ahmadu Bello University, Zaria.

Oladejo, M. J. \& Awolusi, O. D. (2018). Effect of Work-Family Role Conflicts on Employees Commitment and Organizational Performance: A study of AKLAD Interlink concept, Nigeria, Global Journal of Commerce and Management Perspective, 7(2), 81-96.

Rampersad, C. A. (2011). Teachers 'perceptions of the Contribution of Information and Communication Technology To The Teaching of Modern Studies, Using An Integrated System, In An Urban Secondary School (Doctoral dissertation, The University of the West Indies).

Tapscott, D. (1998). Growing up digital: The rise of the Net generation, New York: McGraw-Hill. 


\section{Journal of Education and Vocational Research (ISSN 2221-2590)}

Vol. 10, No. 2, pp. 47-64 December 2019

Pitan, O. S. \& Muller, C. (2019a). University reputation and undergraduates self-perceived employability: mediating influence of experiential learning activities, Higher Education Research \& Development, $38(6), 1269-1284$.

Pitan, O. S. \& Muller, C. (2019b). Students' self-perceived employability (SPE): Main effects and interactions of gender and field of study, Higher Education, Skills and Work-Based Learning, Vol. 10(2), 355-368.

Polit, D. F. \& Hungler, B. P. (1997). Essentials of nursing research: Methods, appraisals and utilisation. 4th edition. Philadelphia: Lippincott-Raven Publishers.

Roos, G. (2005). Educational Plan Implementation Strategy, Supporting Documentation. Gauteng On-Line (GoL), 21.

Shafika, I. J. (2007). Survey of ICT and education in Africa: South Africa Country Report.

WEF. (2015). The Global Information Technology Report. 